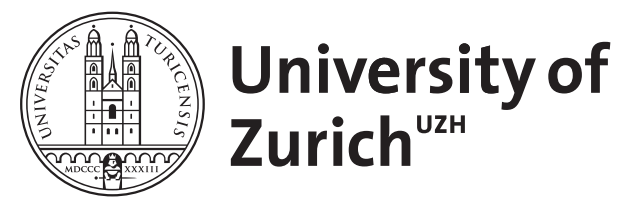

\title{
Linguistic replacement in the movies
}

Bleichenbacher, Lukas

\begin{abstract}
In this paper, I discuss the use of the English language in movie dialogues where, logically, other languages would have been used by the fictional characters. A shared characteristic of many Hollywood movies (as well as countless other fictional narratives, written or performed) is the notion of linguistic replacement. Even when the depicted story would realistically have taken place in a different linguistic setting, the language(s) are replaced by the base language of narration; in my case, English. Using a taxonomy of semiotic strategies proposed by Petr Mareš as a point of departure, I discuss examples of linguistic replacement from a corpus of twelve recent, commercially successful Hollywood movies with European and American settings. I argue that even though the different strategies (e.g. the use of L2 accents or the presence of the replaced language in filmed writing) fulfill more complex symbolic functions than that of compensatory realism, there has been a recent shift away from linguistic replacement altogether
\end{abstract}

DOI: https://doi.org/10.2478/v10010-008-0008-9

Posted at the Zurich Open Repository and Archive, University of Zurich

ZORA URL: https://doi.org/10.5167/uzh-153912

Journal Article

Published Version

Originally published at:

Bleichenbacher, Lukas (2008). Linguistic replacement in the movies. Poznan Studies in Contemporary Linguistics, 44(2):179-196.

DOI: https://doi.org/10.2478/v10010-008-0008-9 


\title{
LINGUISTIC REPLACEMENT IN THE MOVIES ${ }^{1}$
}

\author{
LUKAS BLEICHENBACHER \\ University of Zurich \\ lbleichenbacher@es.uzh.ch
}

\begin{abstract}
In this paper, I discuss the use of the English language in movie dialogues where, logically, other languages would have been used by the fictional characters. A shared characteristic of many Hollywood movies (as well as countless other fictional narratives, written or performed) is the notion of linguistic replacement. Even when the depicted story would realistically have taken place in a different linguistic setting, the language(s) are replaced by the base language of narration; in my case, English. Using a taxonomy of semiotic strategies proposed by Petr Mareš as a point of departure, I discuss examples of linguistic replacement from a corpus of twelve recent, commercially successful Hollywood movies with European and American settings. I argue that even though the different strategies (e.g. the use of L2 accents or the presence of the replaced language in filmed writing) fulfill more complex symbolic functions than that of compensatory realism, there has been a recent shift away from linguistic replacement altogether.
\end{abstract}

KEYWORDS: multilingualism; movie dialogues; linguistic landscape; language ideology; codeswitching.

\section{Introduction}

In this paper, I discuss the use of the English language in movie dialogues where, logically, other languages would have been used by the fictional characters. A shared characteristic of many Hollywood movies (as well as countless other fictional narratives, written or performed) is the notion of linguistic replacement. Even when the depicted story would realistically have taken place in a different linguistic setting, the language(s) are replaced by the base language of narration; in my case, English. Thus, German composers, Russian submarine commanders, and Polish pianists speak English, rather than - more logically - German, Russian, or Polish. Throughout the history of artistic representations of language use, audiences and critics have mostly accepted this

\footnotetext{
${ }^{1}$ This article is an extended and upgraded version of a paper read at the 38th Poznan Linguistics Meeting. My thanks go to Małgorzata Haładewicz-Grzelak and to two anonymous reviewers, as well as to Anna Bernold and Paris De Belder for the Russian and Spanish transcriptions, respectively.
} 
sacrifice of realism for the sake of comprehension. Still, a central task of narration in any texts with linguistic replacement is to prevent the reader or viewer from assuming that in the fictional world of the story or fabula (Bordwell 1985), the characters would really have spoken English (or any other base language of narration), especially if mistaken assumptions about the sociolinguistic setting can result in serious misunderstandings of the narrative.

My starting point is a taxonomy proposed by the Czech scholar Petr Mareš, who distinguishes between different linguistic and non-linguistic means to make the process of replacement, as well as the nature of the replaced languages, obvious to the viewer. Mareš's strategies of elimination, signalization, and evocation are characterized by different visual or aural hints both to the process of replacement as such as well as to the nature of the language replaced. The strategies are then illustrated by a small corpus of twelve recent, commercially successful Hollywood movies with European and American settings. My claim is that these strategies, as well as the partial presence of the replaced languages in certain contexts, fulfill more complex symbolic functions than a simple strategy of compensatory realism. Moreover, despite the narrative profit that can be drawn from the strategies, there has been a recent shift away from linguistic replacement altogether, as I argue in my conclusion.

\subsection{The replacement strategies}

Mareš's (2000a, 2000b, 2003) taxonomy of representations of multilingual discourse in fictional texts is based on the notion of a continuum from the complete elimination of languages other than the base language (in my case, English) to their complete presence. The taxonomy focuses on characters' direct speech, since that is the preferred site for other languages to appear. Mareš's central notion is that whenever another language would be used by a character within the reality of the story ("in the fictional world"; Mareš 2000a: 51), the narrator chooses whether to represent the other language faithfully or to replace it, either through complete elimination or one of two intermediate strategies, signalization and evocation. Table 1 gives an overview of Mareš's taxonomy.

In the first strategy, elimination, any speech that would have been in another language is completely replaced with an unmarked standard variety of the base language. There, the audience is offered no linguistic means of realizing that the other language is replaced at all, unless they correctly interpret contextual evidence which shows that in reality, it is unlikely or impossible that the characters would really have used the base language. Their task is alleviated in the case of signalization, where the replaced language is explicitly named in a metalinguistic comment. The third strategy, evocation, is used when characters speak a variety of the base language that is characterized by interference (transfer) from the language they would really be speaking. For instance, a Spanish accent or a number of short code-switches from English into Span- 
Table 1. A taxonomy of multilingualism in fictional texts, based on Mareš (2000a, 2000b, 2003).

\begin{tabular}{|c|c|c|c|c|}
\hline & $\begin{array}{l}\text { Most distant } \\
\text { from depicted re } \\
\text { ality }\end{array}$ & & & $\begin{array}{l}\text { Closest to } \\
\text { depicted reality }\end{array}$ \\
\hline Strategy & Elimination & Signalization & Evocation & Presence \\
\hline $\begin{array}{l}\text { Treatment } \\
\text { of other } \\
\text { languages }\end{array}$ & $\begin{array}{l}\text { Neither used } \\
\text { nor mentioned }\end{array}$ & $\begin{array}{l}\text { Named by } \\
\text { the narrator } \\
\text { or by characters }\end{array}$ & $\begin{array}{l}\text { Evoked by means } \\
\text { of L2 interference } \\
\text { phenomena }\end{array}$ & Used \\
\hline $\begin{array}{l}\text { Audience's } \\
\text { awareness } \\
\text { of other } \\
\text { language(s) }\end{array}$ & $\begin{array}{l}\text { Depends } \\
\text { on ability } \\
\text { to process } \\
\text { extralinguistic } \\
\text { hints }\end{array}$ & $\begin{array}{l}\text { Through } \\
\text { metalinguistic } \\
\text { comments }\end{array}$ & $\begin{array}{l}\text { Depends } \\
\text { on correct } \\
\text { interpretation of } \\
\text { interference } \\
\text { phenomena }\end{array}$ & Full \\
\hline $\begin{array}{l}\text { Audience's } \\
\text { comprehension } \\
\text { of content }\end{array}$ & Full & Full & $\begin{array}{l}\text { Full, provided } \\
\text { the audience } \\
\text { is unwilling } \\
\text { to listen to } \\
\text { "non-native"2 }\end{array}$ & $\begin{array}{l}\text { None, unless } \\
\text { the other } \\
\text { language is } \\
\text { somehow } \\
\text { translated }\end{array}$ \\
\hline
\end{tabular}

ish can evoke an utterance that would have been in monolingual Spanish in reality. There, an important side aspect is that evocation is often only used for the speech of certain characters, rather than all who would logically speak the other language (see Lippi-Green 1997: 84; and Grutman 2002: 333). Finally, the other language is no longer replaced at all when the strategy of presence is used. Unless the audience is highly multilingual, comprehension becomes an issue in these cases. In written texts, adding translations potentially results in an interruption of the flow of reading, whereas in movies, comprehension is enhanced by the "multiple, overlapping signifiers" (Kozloff 2000: 223f.; see also Busch 2004: 281f.) of the images that underlie the dialogue, and of course by the option of a written translation in subtitles. Their acceptance and use have certainly increased a great deal since 1970, when Forster (1970: 13) stated that "[1]ess use has been made of this medium than one might think; the convention of live theatre has been too strong". Still, many would agree with what Kellman (2000: 110) considers a piece of "conventional wisdom in Hollywood": that, with very few exceptions, "Americans do not go to movie theatres in order to read". Thus, it seems that the use of replacement strategies in Hollywood movies is strongly bolstered by a preference on the side of filmmakers to adhere to norms and ideologies of monolingualism (see also Bleichenbacher 2007, 2008).

\footnotetext{
${ }^{2}$ I am grateful to one of the anonymous $P S i C L$ reviewers for pointing out to what extent audience reactions to non-standard and non-native varieties differ across cultures. See Lindemann (2005) for an account of folklinguistic perceptions of "broken English" in the US.
} 


\subsection{The corpus of replacement movies}

Table 2 lists the twelve movies analyzed alphabetically by title, with an indication of their year of release, genre, and the most prominent languages other than English that are replaced (or sometimes used; see section 4 below), in the dialogues:

Table 2: List of movies with replacement of other languages.

\begin{tabular}{|c|c|c|c|}
\hline Movie & Year & Genre & Major other languages \\
\hline Amadeus & 1984 & Historical drama & German, Italian, Latin \\
\hline Clear and Present Danger & 1994 & $\begin{array}{l}\text { Action thriller } \\
\text { (Jack Ryan) }\end{array}$ & Spanish \\
\hline GoldenEye & 1995 & $\begin{array}{l}\text { Action thriller } \\
\text { (James Bond) }\end{array}$ & Russian \\
\hline Hannibal & 2001 & Action thriller & Italian \\
\hline The Hunt for Red October & 1990 & $\begin{array}{l}\text { Action thriller } \\
\text { (Jack Ryan) }\end{array}$ & Russian \\
\hline Licence to Kill & 1989 & $\begin{array}{l}\text { Action thriller } \\
\text { (James Bond) }\end{array}$ & Spanish \\
\hline The Living Daylights & 1987 & $\begin{array}{l}\text { Action thriller } \\
\text { (James Bond) }\end{array}$ & $\begin{array}{l}\text { Slovak, Russian, German, } \\
\text { Afghani }\end{array}$ \\
\hline The Pianist & 2002 & Historical drama & Polish, German \\
\hline Schindler's List & 1993 & Historical drama & $\begin{array}{l}\text { German, Polish, Hebrew, } \\
\text { Yiddish }\end{array}$ \\
\hline Tomorrow Never Dies & 1997 & $\begin{array}{l}\text { Action thriller } \\
\text { (James Bond) }\end{array}$ & German, Chinese \\
\hline A View to a Kill & 1985 & $\begin{array}{l}\text { Action thriller } \\
\text { (James Bond) }\end{array}$ & French, German \\
\hline The World Is Not Enough & 1999 & $\begin{array}{l}\text { Action thriller } \\
\text { (James Bond) }\end{array}$ & Russian \\
\hline
\end{tabular}

The 12 movies considered are all well-known and commercially successful Englishlanguage movies released between 1984 and 2001, set in Europe and America, and with situations of language contact and the use of languages other than English prominently appearing in the story. The prime narrative reasons which bring the characters into contact are international conflicts, terrorism, and cross-border crime. Six of the movies belong to the James Bond series, while two feature the CIA Agent Jack Ryan interacting with members of the Soviet Navy (in The Hunt for Red October) and with Colombian drug tycoons (in Clear and Present Danger). A further movie with a contemporary setting is Hannibal, which is part of a series featuring the psychopathic serial killer Hannibal Lecter, who is shown living under a false identity in Florence (Italy). Finally, three movies fall under the category of historical drama. Amadeus depicts the relationship between the Italian composer Antonio Salieri and his Austrian counterpart Wolfgang Amadeus Mozart in 18th century Vienna. In stark contrast, in Schindler's List and The 
Pianist the focus is on the effect of the Shoah (Holocaust) in Nazi-occupied Poland in World War 2. In the following section, I turn to the first two of Mareš's categories.

\section{Analysis}

\subsection{Elimination and signalization}

Elimination is characterized by the complete absence of any linguistic hints as to the nature of the language(s) replaced. Instead, the viewers may be offered relevant extralinguistic information, which enables them to become aware of the replacement. Since languages are typically associated with geographic entities, such as nation-states or well-known cities, geographical setting often permits sociolinguistic inferences (and also the other way round). Some viewers may also watch movies with previous knowledge: they may know that parts of Hannibal were filmed on location in Florence, that Amadeus is about an Austrian composer, or that Sean Connery was cast as a Soviet submarine commander for The Hunt for Red October. These viewers may then be well aware of the fact that some characters in these movies would speak Italian, German, or Russian, even if in the movie they speak English. For other viewers, who lack this previous knowledge, a straightforward technique is to name the geographic location of the scenes. Superimposed titles are one way of doing so, as in the opening scene of The Pianist, where "WARSAW 1939" can be read: the viewer knows that the setting is Polish, and an educated guess is that the English spoken replaces the Polish language or, possibly, any other languages spoken in Central and Eastern Europe during the period. Very similarly, superimposed titles at the beginning of Schindler's List name "September 1939 " as the moment of the Polish army's defeat by the Germans, and of the beginning of the Nazi resettlement of Jews: "More than 10,000 Jews from the countryside arrive in Krakow daily". Shortly afterwards, deported Jews are shown queuing up at registration desks on a railway platform, and a large sign in the background reading "KRAKÓW GŁÓWNY" ('Krakow main [station]') links the superimposed text to the images. Two further examples are the Bond movie The Living Daylights, where the title "BRATISLAVA, CZECHOSLOVAKIA" appears right after the opening credits, and GoldenEye, where a massive dam (in real life, the Contra dam in Ticino, Switzerland) is glossed over as "ARKANGEL CHEMICAL WEAPONS FACILITY - USSR".

Another strategy to indicate geographical locations is to show well-known landmarks or to exploit the conventional meaning of symbols on flags. When the narrative of Hannibal moves from the US East Coast to Florence in Northern Italy, we first see a wide shot of the well-known Dome, followed by a short sequence where Dr Lecter's antagonist, the police officer Pazzi, is standing on the famous Piazza della Signoria, with the replica of Michelangelo's Davide statue clearly in sight. Later in the movie, a short scene takes place at a bank in Geneva, and the transaction is conducted in a room adorned by the flags of both Switzerland and the canton of Geneva. In contrast, the 
movie Amadeus does not make use of any visual hints with regard to its setting. Instead, a dialogue at the beginning of the movie contains the following lines: ${ }^{3}$

Excerpt 1 (Amadeus, 0:06.28 - 0:06.41)

$[\ldots]$

Salieri How well are you trained in music?

Father Vogler I know a little. I studied it in my youth.

Salieri Where?

Father Vogler Here in Vienna.

$[\ldots]$

By combining the name of the capital city of the Austrian Empire with the deictic adverb here, Father Vogler (who acts as the protagonist Salieri's confessor in this scene) clearly states that the movie is set in a German-speaking environment. Still, different languages are used in Amadeus: Salieri is obviously of Italian origin; he is addressed in a mixture of Italian and English in the opening scene of the movie, and further Italian characters appear shortly afterwards at the Emperor's Court, as well as in some scenes set on opera stages. Moreover, some religious settings feature the use of Latin. To point to the German language in a more obvious way, the metalinguistic strategy of signalization is used. The following excerpt features the Austrian Emperor Joseph, discussing his plan to commission an opera from Mozart with his political and artistic advisors:

Excerpt 2 (Amadeus, 0:24.05-0:25.10)

$[\ldots]$

Joseph

Well then, we should make some effort to acquire him. We could use a good German composer in Vienna, surely? I'm sure he could be tempted with the right offer. Say erm an opera in German for our national theatre.

Van Swieten Excellent sire.

Orsini-Rosenberg But not in German, I beg Your Majesty. Italian is the proper language for opera. All educated people agree on that.

Joseph M-hm. What do you think, Chamberlain?

Von Strack In my opinion, Sir, it's time we had a piece in our own language. Plain German for plain people.

Joseph M-hm. Kapellmeister?

\footnotetext{
${ }^{3}$ Normal print indicates dialogue in English, bold print dialogue in another language, and italic print comments on the transcribed scene. SMALL CAPS reproduce the original movie subtitles; where these are missing, the speaker turns are followed by translations ('within brackets and single inverted commas').
} 
Bonno Majesty, I must agree with Herr Direttore. German is, scusate ['excuse me'], too brute for singing.

$[\ldots]$

Signalization is defined as the literal naming of a language in the text, and in this scene, the naming of the German language serves additional narrative purposes. The viewer's attention is drawn to a language hierarchy, reminiscent of diglossia, which is defended by some characters but contested by others, including (shortly afterwards in the movie) Mozart himself. The reference to Italian as the "right" language for opera motivates and underlines the influential position of the Italian characters - especially Salieri, Mozart's envious opponent - in the story. Moreover, it announces the ensuing conflicts between Mozart, who is many ways a representative of the "plain people", and his more elitist adversaries among the Viennese nobility. Finally, it prepares the Mozart aficionados among the audience for a particularly strict feature of the replacement strategy used in Amadeus: the fact that no German is sung on any of the stages. Whereas lyrics are often left in the original language in replacement movies, in Amadeus this only applies to Italian. In contrast, the excerpts from The Abduction from the Seraglio and The Magic Flute - both operas with German libretti - are sung in English, and English is also used in a scene featuring a German-language parody of Don Giovanni - one of Mozart's Italian operas - that is staged at a popular theatre. Very consistently, German is not only replaced by English in the characters' conversations, but also as a literary register in the lyrics of vaudevilles and operas. In contrast, Italian is present in Amadeus whenever its use within the story appears as realistic.

Signalization appears as a straightforward and useful technique, but it requires the viewer to be attentive at the very moment when the name of the language is uttered. Furthermore, a recurrent use of signalization in the same text is likely to appear as oddly redundant, unless there is a strong narrative motivation for such metalinguistic comments. Apart from Amadeus, the only movie in the corpus with obvious signalization is Hannibal, where the Italian language is mentioned in the context of Italian Renaissance literature. This might explain why in Mareš's approach, signalization is only used with reference to written texts, but not cinematic ones. For the latter, evocation appears as a more sensible strategy, because it permits the viewer to keep the replaced language in mind throughout the movie.

\subsection{Evocation}

Evocation is defined as the use of a marked variety of English (the base language), characterized by interference from the replaced language. Although it is a very common strategy, its main shortcoming lies in the fact that an L2 variety (such as English with a Spanish accent) is used to replace what in reality would be an L1 variety of Spanish (or any other language). This paradox can cause a number of problems. Firstly, it can fuel 
language ideologies according to which anybody who is not an L1 speaker of English is somewhat linguistically challenged. Secondly, there is the challenge of distinguishing instances of evocation from conversations where the (same) characters are indeed speaking English, as L2 users with the same accents or other interference phenomena. Moreover, a very ignorant viewer might even be tricked into the belief that English is the only language spoken around the world - "natively" by its L1 speakers, and with funny accents by everyone else. Finally, an overall use of L 2 accents by every character runs counter to an important narrative convention: the use of non-standard language for contrastive characterization only. It is probably this last feature which explains why the extent to which evocation characterizes the speech of different characters varies greatly in many movies.

\subsubsection{Accents and code-switching}

In theory, evocation could appear on any level of linguistic analysis, but phonology (L2 accents) and lexis (code-switches into the other language for certain words or phrases) are clearly its preferred sites. Instances of morphosyntactic interference used for evocation are practically inexistent (see Herbst 1994: 126), precisely because they would point to an L2 variety in an all too confusing manner. From the point of view of acting, lexis is certainly a more convenient method, in that anybody can utter words or longer utterances in unknown languages, whereas not all actors are equally gifted at imitating certain accents (see Lippi-Green 1997: 84). One solution to this problem is to cast L1 speakers of the replaced language(s) as actors, given that they should have no problem performing the requested accents. This clashes, however, with Hollywood's preference for stars whose first language is English to play the main characters. In some cases, actors with a non-English L1 are cast in minor roles, where they speak English with marked L2 accents; a pattern which occurs in several of the movies analyzed, for instance in Schindler's List and The Pianist. Moreover, the English-speaking stars who impersonate the leading characters may contrive an L2 accent as well (this strategy is generally employed in Schindler's List) - or indeed abstain from doing so altogether. The replacement of German in Amadeus is the most extreme example of the latter strategy, where evocation is used by a single character and in a single scene only. The scene is set in a barber shop, where Mozart has come to find a suitable wig for his impending audience at the Emperor's Court:

Excerpt 3 (Amadeus, 0:26.12 - 0:26.46)

Barber Ei ei ei this is a beautiful wig for you. Es looks so marvellous and I love it.

Mozart The other one.

Barber Here is the other one. I think you will love it. 
$\begin{array}{ll}\text { Barber } & \text { Here is the third one. So. Here we go. How do you like it? } \\ \text { Mozart } & \text { They're all so beautiful. Why don't I have three heads? (laughs) } \\ \text { Barber } & \text { This is funny! (laughs and applauds) Three heads! Ha! }\end{array}$

The barber has a marked German accent, and switches into German for three short utterances: the interjection ei ei ei (used to indicate surprise or similar emotions), the personal pronoun es 'it', and the discourse marker so 'so'. As further features that are potentially indicative of interlanguage, one can mention the reliance on repetitions (love it; Here is the...), the odd coordination in It looks so marvellous and I love it, and the slight redundancy of the observation This is funny. The barber's overall linguistic clumsiness is contrasted by Mozart's concise order (The other one), as well as by his imaginative joke about the three heads; needless to say, the composer's accent is not German, but American. As a whole, the scene provides light amusement at the expense of German speakers: the only character with a German accent in Amadeus is indeed an effeminate, slightly ridiculous, and comical character. Moreover, what seems odd from the point of view of realism is that Mozart's and the barber's linguistic skills appear to be very different, whereas in reality, they would have been largely identical.

An altogether different pattern of phonological evocation appear in The Hunt for Red October, where English replaces Russian in a number of scenes set in and around two Soviet submarines. In the use of L2 accents by the Russian characters, three categories can be distinguished in terms of military hierarchy and narrative importance: the protagonist and his main opponent, a number of secondary characters with medium importance, and minor characters such as seamen or officers with only one or few speaker turns in the movie. The latter characters, who also occupy the lowest position in the military hierarchy within the story, have mostly Russian accents, and some of them are also impersonated by Eastern European actors. The more important characters are played mostly by British actors, who use standard British accents, irrespectively of whether they are good guys, such as the protagonists' loyal supporter, Captain 2nd Rank Borodin, or more negative characters, such as Political Officer Putin, or the annoyingly doctrinaire ship's doctor Petrov. A Russian accent is not even used by the deceitful Russian ambassador Lysenko, even though this character's use of English is logically plausible, and not part of a replacement strategy. Then, there are the protagonist Captain Ramius and his antagonist, Captain Tupolev, who use different varieties of English again. For Ramius, the actor Sean Connery's idiosyncratic Scottish accent distinguishes the character from the RP speakers among the Soviets, which adds credibility to the portrayal of Ramius as of Lithuanian (as opposed to Russian) origin. Likewise, Tupolev is played by the Swedish actor Stellan Skarsgård, whose English also features a different accent from those of the other Russian characters. While this pattern may appear fairly complex, it has one major advantage: no American accents are used for any replacement of Russian, which prevents any confusion that could arise, due to frequent changes of setting, between the Soviet and US characters. Here and elsewhere, the 
filmmakers exploit the fact that the English language is known in two distinct and, broadly speaking, equally prestigious standard accents.

\subsubsection{Other forms of evocation}

So far, the discussion of evocation has mainly focused on accents and the use of short code-switched words from the other language, such as the German $e i$ and $j a$ in the examples quoted above, or, as another example, in the Italian pronto ('ready'; the usual turn to answer a phone call) in Hannibal. A further strategy is the use of words or expressions from the replaced language which, due to their high cultural specificity, index a different language and are hard to render in English anyway. A first case in point are given names: characters in replacement movies typically bear names that are obviously non-English, and their effect can be reinforced when culture-specific naming patterns are depicted. These include Russian names, where the first name is usually followed by a patronym, as in GoldenEye, where General Ourumov is addressed as Arkadij Grigorovich $^{4}$ in one scene. Another example are hypocorisms (nicknames based on personal names) derived via language-specific word formation processes. In Amadeus, the German hypocorisms for Wolfgang and Constanze, Wolfie and Stanzi, can pass as German as well as American English - however, the latter hearing is encouraged by Constanze's pronunciation of the first vowel in Wolfie as ['vulfi] rather than German ['volfi]. In contrast, a clearly non-English abbreviation of a first name is used in The Pianist. The protagonist's first name, Wladyslaw, is replaced by Wladek by his family members and his close friends, such as Dorota in this excerpt:

Excerpt 4 (The Pianist, 0:09.45-0:09.52)

$[\ldots]$

Dorota Oh Mr Szpilman, you are quite quite wonderful.

Szpilman
Call me Wladek please.

The word formation process which renders Wladyslaw as Wladek, back-clipping and adding of a diminutive velar suffix, is typical for Polish (and other Slavonic languages). Polish titles are not used in The Pianist, though: Dorota addresses Wladek as Mr, not Pan Szpilman. In contrast, titles in the replaced language are extensively used in Amadeus; examples include German Herr 'Mister', Frau 'Mrs', or Fräulein 'Miss', as well as Italian Signore 'Mister'. The titles Court Composer and Emperor are given in Eng-

\footnotetext{
${ }^{4}$ I reproduce all names of characters as they appear in the movie credits, with no attempt to supply missing diacritics, "correct" anglicized spellings, or harmonize different transliterations of identical syllables across different movies.
} 
lish, while the Italian Bonno is called Kapellmeister 'Chief Conductor'. In Schindler's List, the protagonist is addressed as Herr Direktor, and military titles of the SS such as Scharführer, Hauptscharführer and Untersturmführer are inserted into English utterances. A further sub-strategy exploits the different language versions of place names: whereas the English equivalents of foreign place names are often used when they exist (as in excerpt 1 above), the Italian place name Firenze is used in Hannibal instead of Florence.

Two further categories of culture-specific expressions are greetings and terms of mild or strong abuse. In the movies analyzed, non-English greetings only appear in Hannibal (It. buon giorno" 'good day' and buona sera 'good evening'), and in the special case of Goeth's Heil Hitler, which constitute the last spoken words in the movie, in a brief sequence showing the brutal camp commander's execution. Conversely, there is a more even distribution of terms of abuse: the Russian word svin 'ja 'pig' occurs in GoldenEye, while the Spanish gringo and cojones are uttered in The Living Daylights. As a rare and inventive example of a crosslinguistic calque, a Russian IT nerd in GoldenEye teases his colleague by calling her boršč-for-brains after the well-known Russian vegetable soup.

In the next section, I move from the aural evocation of other languages to their partial presence, in the use of filmed writing as well as after unrealistic code-switches.

\section{Partial presence}

\subsection{Linguistic landscape}

Replacing other languages in writing can be considered a very marked strategy because it results in a visual, rather than just aural, falsification of the depicted reality. While viewers can put up with English-speaking characters in 1940 Warsaw, an English billboard in their background would certainly be met with puzzled reactions. Therefore, the linguistic landscape of the movies, which includes public signs as well as filmed documents, are usually left in the original language. While exceptions to this pattern exist (typically in historical movies, such as The First Knight, 1995 or The Three Musketeers, 1993) there was no clear-cut instances of English writing replacing other languages in the corpus. One borderline case, which occurs in GoldenEye, depicts an online exchange of instant messages between two Russian scientists in St. Petersburg - all of which are in English. It is rather unlikely, but not completely impossible, that the two characters (who both know English) would have used this language (rather than Russian, even in Latin script). For the viewer however, it is obviously more convenient to read this text in English, rather than to be confronted with subtitles accompanying the writing on the screen. In turn, the excerpt conveys the notion that the Russian language may not be quite as suitable for electronic communication as English. 
In other spy thrillers, bilingual signs in English and the replaced language function as a semiotic way of having one's cake and eating it, too. In a scene in The Hunt for Red October, a Russian map of the Atlantic Ocean features the names for some subaqueous landmarks in Cyrillic script as well as accompanied by their English equivalents. For the viewer, the impression of realism is combined with the possibility to read the place names, and especially to recognize a location which had previously been mentioned in an English dialogue. A similar example occurs in The World Is Not Enough, where James Bond assumes the false identity of a Russian scientist to get access to a nuclear site in Kazakhstan. Bond is almost exposed when he fails to observe a standard procedure upon entering the site - collecting a radiation tag - and his attention is promptly directed to a large warning sign, which reads WARNING - RETURN ALL RADIATION TAGS TO THIS CHECK POINT WHEN LEAVING, followed by a Russian translation. The character of James Bond would have known enough Russian to understand a monolingual sign with no English translation, but for the viewer, the interaction would have remained opaque. At the same time, the presence of the English language on the sign is perfectly plausible since the nuclear site is portrayed as an area of Russian and US cooperation, and Bond's interlocutor, Dr Christmas Jones, is American herself.

In many cases, however, the exact content of the writing is less relevant. In a shot of a Viennese alley in Amadeus, the shop sign Friseur und Perückenmacher 'barber shop and wig maker' is visible, but since the scene occurs much later than Mozart's actual visit to the barber shop (see Excerpt 3 above), there is no special need for the viewer to read and comprehend the sign at this stage; its function is one of mere realism. Likewise, the final scene of The Pianist shows an army camp where the victorious Red Army has assembled German prisoners. A banner in the background reads ВПЕРЕД НА БЕРДИН!, and while the Cyrillic writing itself simply underlines the fact that the soldiers are indeed Russian, the exact meaning (vpered na Berlin; 'onwards to Berlin') adds a sense of historical accuracy, again without carrying any strict narrative relevance.

A different case occurs earlier in The Pianist, during a conversation between Szpilman and his gentile friend Dorota. The two are walking through the streets of Warsaw shortly after the German invasion, and as Szpilman intends to invite her to a café, they become aware of a sign on the door that had not been there previously. The sign $\dot{Z} Y$ DOM WSTĘP WZBRONIONY, which is shown in close-up, is both highly relevant for the narrative: it upsets both characters and is a first and, at least in comparison, relatively harmless announcement of the occupiers' genocidal policy. At the same time, the sign is incomprehensible; even the word $\dot{Z} y$ dom (Polish 'for Jews') is far too remote a cognate for most viewers to recognize. Of the two most obvious strategies, a character reading the sign in English or a subtitle being added, the latter is chosen: "NO ENTRY FOR JEWS" (The Pianist, 0:08.43).

Much like many instances of multilingualism in fiction, sociolinguistic realism in the depiction of multilingual landscapes is also invested with symbolic functions. As already mentioned, the beginning of Schindler's List contains a scene at a railway station, with the Krakow main station's Polish name visible above the platform. Later in the 
movie, when the Nazi occupation is firmly established, the Polish sign is replaced by a German one: "KRAKAU Hbf.". While there is nothing unusual about the monolingualism of the original sign, the Nazi's decision not to include the Polish language in their revision of the linguistic landscape serves as one further indicator of their brutality and ruthlessness. Interestingly however, a different signing policy is depicted towards the end of the movie, when Schindler has managed to guarantee his workers a safe passage from Poland to Moravia. The railway station of Schindler's home town is marked in two languages, Czech and German: "BRNĚNEC-BRÜNNLITZ". This difference in signing policy may be due to historical circumstances with little relevance for an appreciation of Schindler's List. However, on a symbolic level, it mirrors the extent to which Brünnlitz is a safe haven for Schindler's workers. Although they are still clearly within Nazi territory, they no longer fear deportation, and Schindler even manages to keep the German soldiers at bay. A comparable instance of bilingual symbolism occurs in the very last scene of Schindler's List. The surviving Schindler Jews are showed paying tribute at Schindler's tombstone, on which a Hebrew and German text appear side by side, as if to suggest the possibility of a reconciliation between Germans and survivors of the Shoah.

\subsection{Unrealistic code-switching}

To round off this discussion of partial presence, it is useful to describe a specific narrative strategy which poignantly highlights the difference between replacement and presence by juxtaposing them within the same conversational interaction. The first example is from the Jack Ryan thriller Clear and Present Danger, which starts with a sequence where US Coast Guards find the murdered family of an American businessman in a yacht which had been captured by South American killers off the coast of Florida. The CIA analyst Jack Ryan soon suspects that the killing is somehow related to Colombian drug cartels, and shortly afterwards, the narrative moves to an impressive Colombian hacienda. There, the entrepreneur Ernesto Escobedo is shown practising baseball, when he is addressed by Felix Cortez, his inscrutable security advisor:

Excerpt 5 (Clear and Present Danger, 0:09.39 - 0:10.32)

$[\ldots]$

Cortez

Escobedo
Tu sabes lo qué has hecho, no?

DO YOU KNOW WHAT YOU'VE DONE?

Maté a un ladrón. Maté a un ladrón que me estaba robando. A mí!

I KILLED A THIEF. I KILLED A THIEF WHO WAS STEALING... FROM ME! 
Cortez

Escobedo

Cortez

Escobedo

Cortez

Escobedo
Y a su mujer, y a su hijo, y a su hija, aparentemente sin pensar en las consecuencias.

AND HIS WIFE, SON AND DAUGHTER, WITH NO THOUGHT OF THE CONSEQUENCES.

Oh, sí señor. Para que sus hijos venguen la muerte de su padre cuando menos lo espero.

SO HIS KIDS SHOULD GROW UP TO REVENGE THEIR FATHER'S DEATH

- WHEN I LEAST EXPECT IT ...?

Ese tío era un gran amigo y un aliado político del presidente de los Estados Unidos.

HE WAS A GOOD FRIEND AND POLITICAL ALLY OF THE PRESIDENT OF THE U.S.

That doesn't surprise me.

It should at the very least concern you.

What are they going to do. Come after me? Arrest me? You're scaring me.

$[\ldots]$

The subtitled Spanish dialogue at the beginning of the scene informs the viewer that Escobedo gave the order to kill the American - apparently a dishonest business partner - and his family without having asked for Cortez's advice. Cortez is visibly irritated, but initially, Escobedo does not appear to take him seriously, and continues hitting the balls while talking back to Cortez. Cortez then explains his disapproval: he fears retaliatory action from the American government, because the murdered businessman was a close friend of the US President. At this precise moment, Escobedo is surprised and distracted from batting; he misses the next ball, which is shown rolling away in a brief instance of slow motion. When Escobedo answers Cortez, he is suddenly speaking English, which remains the language of conversational interaction among Spanish speakers in all further scenes of Clear and Present Danger. The characters on screen have changed from Spanish to English although within the reality of the story, it is clear that they would not have done so.

This strategy can be named unrealistic code-switching because it operates exclusively on the level of narration, and not within the story. Unrealistic code-switches are highly marked phenomena, in that they expose the semiotic absurdity of replacement by contrasting it with the more realistic presence. The fact that they qualify as ruptures of the narrative process explains the use of slow motion in the scene quoted above. However, as the last Spanish expression in the interaction, the words "Estados Unidos" ('United States') appear as a likely trigger for a switch from Spanish into English. Thus, while the unrealistic nature of the code-switch is foregrounded by the cinematographic technique, the linguistic context is skilfully adapted to embed the code-switch in the conversation and even lend it some pragmatic likelihood. 
A second example appears in The Hunt for Red October. Most scenes at the beginning of the movie are among English L1 speakers only, apart from the very first one, where two Russian characters (the protagonist Captain Marko Ramius and his closest ally, Captain 2nd Rank Borodin) exchange four short and subtitled turns in Russian on the cold weather at the home base of the eponymous submarine. Shortly after the Red October has left the base westwards for the Atlantic, Ramius surprises Political Officer Putin perusing Ramius's books in the Captain's cabin:

Excerpt 6 (The Hunt for Red October, 0:14.00 - 0:15.06)

$[\ldots]$

Ramius

Putin

Ramius

Putin

Putin

Ramius

$[\ldots]$
Što ty delaeš'?

WHAT ARE YOU DOING?

V moi objazannosti vxodit nabljudenie nad povedeniem členov èkipaža, tovarišč kapitan.

OVERSEEING THE STABILITY OF THE CREW.

Perexodiš' granicy.

BY INVADING MY PRIVACY?

V SSSR, tovarišč, ličnyx del byt' ne možet. Takoe ponjatie protivorečit obščestvennomu delu.

PRIVACY IS NOT A MAJOR CONCERN IN THE SOVIET UNION. IT IS OFTEN CONTRARY TO THE COLLECTIVE GOOD.

(reading) Se, idu kak tat': Blažen bodrstvujuščij i xranjaščij odeždu svoju. I on sobral ix na mesto, nazyvaemoe po-evrejski "Armageddon". And the seventh Angel poured forth his bowl into the air and a voice cried out from heaven, saying "it is done". A man with your responsibilities reading about the end of the world, ha. And what's this? "I am become death, the destroyer of worlds". "BEHOLD, I AM COMING AS A THIEF. AND THEY GATHERED THEM TOGETHER IN PLACE CALLED ARMAGEDDON".

It is an ancient Hindu text, quoted by an American.

Ramius's turns are very short and to the point, but Putin's language is of a very different style. His arrogant superiority and orthodox adherence to Soviet communism is reflected in his preference for indirect phrasing, his repeated use of the term tovarišč 'comrade', and the way in which his utterances sound as if they were memorized from manuals of doctrine. As a communist, Putin cannot hide his unpleasant surprise, but also amusement at Ramius's literary predilections. While Putin is reading from the Book of Revelation (16: 15-17) in Ramius's copy of the Bible, an unrealistic code-switch takes place. Again, there is a cinematographic correlate: while Putin reads, the camera zooms rapidly onto his mouth, stopping precisely when he utters the word Armageddon, 
and then zooms back until he stops quoting from the Bible (... it is done). There is also a linguistic motivation for the switch: the place name Armageddon appears as a convenient place to switch, since it is neither English nor Russian. In Putin's utterance (though not in the subtitles) it is even preceded by a metalinguistic comment: "nazyvaemoe poevrejski”: '[which is] called in Hebrew'.

One major advantage of unrealistic code-switches is to indicate the replaced language in a clear-cut way, and to foreground the stylistic choice of replacement by performing the transition on screen, with cinematographic highlighting to boot. In a way, unrealistic code-switches can be considered a more "honest" strategy than continuous replacement from the beginning. However, they do not solve the dilemma of a potential misinterpretation: viewers can still be tricked into believing that the characters would really have code-switched into English, especially since the unrealistic codeswitches occur in a pragmalinguistic environment favourable to code-switching, as in both examples quoted above. If this is the case, the impression one might get is that conversations may well begin in other languages, but should be carried on in English thereafter.

\section{Conclusions}

My analysis has shown the advantages and dangers of different strategies available to filmmakers who decide to have their characters speak in English, even if in reality they would have used other languages. Since replacement flouts elementary principles of realistic representation, it is not surprising that pure elimination is rare. Instead, the strategies of signalization, evocation, and partial presence predominate, and are used to fulfil various narrative and symbolic functions. While elimination and signalization are less obtrusive than evocation, they are also more likely to lead to misinterpretations of the depicted reality. Evocation points to the replaced language in a more obvious or even "honest" manner, but it carries the risk of creating an association of second language use with specific and potentially unfavourable aims of characterization. In sum, Mareš's taxonomy has proven to be eminently useful for the analysis, if one bears in mind his observation (Mareš 2000b: 250) that the strategies often coexist within the same texts.

Clearly, these results need to be checked against further evidence from cinematic texts outside the Hollywood mainstream, from different linguistic settings, and also from the dubbed versions of Hollywood movies. The latter analysis would have to discuss, for instance, the extent to which in some dubbed versions, the amount of dialogue in other languages is even smaller than in the English original. For instance, in the Czech version of The Hunt for Red October, there is no unrealistic switch from Russian into Czech (see excerpt 6 above) because the Russian characters speak Czech from the beginning. A similar case are the two movies The Peacemaker (1997) and Traffic (2000), which feature no replacement in the original, but a large amount of non-English 
dialogue instead. In the French dubbed versions of the two movies, however, this dialogue disappears, and the characters use foreign-accented French.

Still, there has been a clear trend away from the replacement of other languages towards the strategy of presenting them whenever their use would seem plausible, especially in movies where the English language is also used realistically. Both in the series of James Bond and Jack Ryan movies, all instances of replacement predate the new millennium, and the strategy of presence (however limited) has been used throughout the three most recent movies, The Sum of All Fears (2002), Die Another Day (2002) and Casino Royale (2006). Likewise, the two most recent movies directed by Mel Gibson constitute the first cases of successful mainstream movies not only without any English dialogue whatsoever, but with subtitled dialogue in languages unknown to a much larger part of the audience than in the case of French, Spanish, or the other languages treated in this study. The first movie is The Passion of the Christ (2004) with dialogue in Aramaic and (to a smaller extent) Latin and Hebrew, and the second is Apocalypto (2006), set in pre-Columbian Central America with dialogue exclusively in Mayan. Gibson's example shows that while the way is certainly paved for more cinematic multilingualism, the ideologies associated with the movies in question do not necessarily coincide with those of many liberally-minded cinemagoers. Moreover, it is fair to assume that Gibson's patterns of linguistic representation remain, at least for the time being, an idiosyncratic choice.

\section{REFERENCES}

Bleichenbacher, L. 2007. “'This is meaningless - It's in Russian': Multilingual characters in mainstream movies". In: Engler, B. and L. Michalcak (eds.), Cultures in contact. (SPELL 17.) Tübingen: Gunter Narr. 111-127.

Bleichenbacher, L. 2008 (forthcoming). Multilingualism in the movies: Hollywood characters and their language choices. (Swiss Studies in English 135.) Tübingen: Francke.

Bordwell, D. 1985. Narration in the fiction film. London: Methuen.

Busch, B. 2004. Sprachen im Disput: Medien und Öffentlichkeit in multilingualen Gesellschaften. Klagenfurt/Celovec: Drava.

Forster, L. 1970. The poet's tongues: Multilingualism in literature. Cambridge: Cambridge University Press.

Grutman, R. 2002. "Les motivations de l'hétérolinguisme: réalisme, composition, esthétique". In: Brugnolo, F. and V. Orioles (eds.), Eteroglossia e plurilinguismo letterario: plurilinguismo e letteratura. Roma: Editrice "Il Calamo". 329-349.

Herbst, T. 1994. Linguistische Aspekte der Synchronisation von Fernsehserien: Phonetik, Textlinguistik, Übersetzungstheorie. Tübingen: Max Niemeyer Verlag.

Kellman, S. G. 2000. The translingual imagination. Lincoln: University of Nebraska Press.

Kozloff, S. 2000. Overhearing film dialogue. Berkeley: University of California Press.

Lindemann, S. 2005. "Who speaks 'broken English'? US undergraduates' perceptions of nonnative English". International Journal of Applied Linguistics 15 (2). 187-212.

$<$ http://www.blackwell-synergy.com/doi/pdf/10.1111/

j.1473-4192.2005.00087.x?cookieSet=1> 
Lippi-Green, R. 1997. English with an accent: language, ideology, and discrimination in the United States. London and New York: Routledge.

Mareš, P. 2000a. "Fikce, konvence a realita: k vícejazyčnosti v uměleckých textech" [Fiction, convention and reality: On multilingualism in artistic texts]. Slovo a slovesnost 61. 47-53.

Mareš, P. 2000b. "Mnogojazyčnaja kommunikacija i kinofil'm” [Multilingual communication and the movie]. In: Rossijskaja Akademija Nauk (ed.), Jazyk kak sredstvo transljatsii kul'tury [Language as a means of translation of cultures]. Moskva: Nauka. 248-265.

Mareš, P. 2003. "Also: nazdar!”: Aspekty textové vícejazyčnosti [“Alright: hello!”: Aspects of textual multilingualism]. Praha: Karolinum.

\section{FILMOGRAPHY}

Amadeus. 1984. (Directed by M. Forman.) The Saul Zaentz Company.

Apocalypto. 2006. (Directed by M. Gibson.) Icon Productions et al.

Casino Royale. 2006. (Directed by M. Campbell.) United Artists et al.

Clear and present danger. 1994. (Directed by P. Noyce.) Paramount Pictures.

Die another day. 2002. (Directed by L. Tamahori.) United Artists et al.

GoldenEye. 1995. (Directed by M. Campbell.) United Artists.

The first knight. 1995. (Directed by J. Zucker.) Columbia Pictures Corporation and First Knight Productions.

Hannibal. 2001. (Directed by R. Scott.) Dino de Laurentiis Productions et al.

The hunt for Red October. 1990. (Directed by J. McTiernan.) Nina Saxon Film Design and Paramount Pictures.

Licence to kill. 1989. (Directed by J. Glen.) United Artists et al.

The living daylights. 1987. (Directed by J. Glen.) United Artists et al.

The Passion of the Christ. 2004. (Directed by M. Gibson.) Icon Productions et al.

The peacemaker. 1997. (Directed by M. Leder.) DreamWorks SKG.

The pianist. 2002. (Directed by R. Polanski.) Studio Canal+ et al.

Schindler's list. 1993. (Directed by S. Spielberg.) Amblin Entertainment et al.

Sum of all fears. 2002. (Directed by P.A. Robinson.) Paramount Pictures.

The three musketeers. 1993. (Directed by S. Herek.) Walt Disney Pictures et al.

Tomorrow never dies. 1997. (Directed by R. Spottiswoode.) United Artists et al.

Traffic. 2000. (Directed by S. Soderbergh.) Initial Entertainment Group et al.

$A$ view to a kill. 1985. (Directed by J. Glen.) United Artists et al.

The world is not enough. 1999. (Directed by M. Apted.) United Artists et al. 